\title{
Health Services of Breast Engorgement on the Postpartum Mothers at Bone Regency South Sulawesi
}

\author{
Mustar $^{1}$, Hasnidar ${ }^{2}$, Indryani ${ }^{3}$ \\ 1,2,3 Institut Sains Dan Kesehatan Bone, Indonesia. \\ Corresponding Author: Mustar
}

\begin{abstract}
Breast milk consists of the nutrients and immunity needed for the growth and development of babies in the first months. Breastfeeding until the end of two years is recommended because it has physiological and psychological benefits for both mother and baby. Lactation failure is often caused by several lactation problems, one of which is the problem of breast engorgement. Postpartum mothers with breast engorgement due to incomplete emptying process of the mammae with breast pain when it is pressed. The purpose of this study is to determine the factors that influence the breast engorgement in postpartum mothers. The research design is a quantitative analytical survey with a cross-sectional approach with a population of 50 respondents and a sample of 35 respondents with purposive sampling technique, data analysis using univariate and bivariate analysis. The results showed that there is a relationship between breastfeeding techniques and the occurrence of breast engorgement with the results of the chi square test statistical test obtained p-value $0.02 \alpha<0.05$, there is a relationship between the condition of the nipple and the occurrence of breast engorgement with the results of the chi square statistical test -value $=0.01 \alpha<0.05$, and there is a relationship between breast care and the occurrence of breast engorgement with the chi square test statistical test results obtained value $=0.03 \alpha<0.05$. There is a relationship between breastfeeding techniques, the condition of the mother's nipples, and breast care with the occurrence of breast engorgement.
\end{abstract}

Keywords: Breast Engorgement, Breastfeeding Technique, Nipple condition, Breast Care

\section{INTRODUCTION}

Breast milk consists of the nutrients and immunity needed for the baby's growth and development in the first months (Elad, 2014). Breastfeeding until the end of two years is recommended because it has physiological and psychological benefits. Lactation failure is often caused by several lactation problems, one of which is the problem of breast engorgement (Wicak Tini Hia 2020). Breast engorgement is caused by incomplete emptying of the mammary glands with signs of breast pain when pressed and emerging discomfort to the mother. (Sitifaidatun, 2019) According to data from the Association of Southeast Asian Nations (ASEAN) in 2014 it was concluded that the percentage of cases of breastfeeding engorgement in postpartum mothers in 10 countries, namely, Indonesia, Thailand, Malaysia, Singapore, Philippines, Brunei Darussalam, Vietnam, Laos, Myanmar and Cambodia recorded 107,654 postpartum mothers, in 2015 there were 95,698 postpartum mothers (66,87\%) postpartum mothers, and 76,543 (71.10\%) postpartum women with the highest number occurred in Indonesia (37.12\%). Based on basic health research data (Ministry of Health RI, 2018) shows that breastfeeding in Indonesia is currently still a concern. The percentage of infants who are breastfeed exclusively until the age of 6 months is only 
$15.3 \%$. In developing countries, the rate of exclusive breastfeeding for infants less than six months is only $37 \%$, and there has been little progress since the early 1990s. The global burden of children who are not exclusively breastfed is estimated to be in the millions of children. (Mufdlilah, 2017)

There are breastfeeding problems, both factors that come from mother and factors that come from baby. The factors that come from the mother are mothers who experience stress, flat or inverted nipples, sore or pain nipples, swollen breasts, breast engorgement, mastitis, breast abscess, lack of breast milk and working mothers. As for the problems that come from the baby, the baby is confused of nipple, the baby is rejecting for breastfed, the baby is born with a weak sucking reflex. (Maryunani 2009) Based on data from the Bone District Health Office, the number of postpartum mothers in 2018 was 14,749 people and 285 people had breast engorgement, in 2019 the number of postpartum women was 14,640 people, 155 postpartum women experienced breast engorgement, and in 2020 the number of postpartum mothers was 14,749 and as many as 177 people experienced breast engorgement (Data from the Bone District Health Office 2021). Meanwhile, according to the medical record data of the Kajuara Health Center, the number of postpartum mothers in 2018 was 148 people, and 35 people experienced with breast engorgement in 2019 the number of postpartum mothers was 183 people, 45 people experienced breast engorgement while the number of postpartum women in 2020 as many as 152 people and experiencing breast engorgement as many as 57 people (Data from the Health Office of Ulaweng Public Health Centre, 2021). Based on the above data related to the high cases of breast engorgement in postpartum mothers, the authors are interested in studying more deeply about health services on the occurrence of breast engorgement in postpartum mothers, Bone Regency, South Sulawesi

\section{LITERATURE REVIEW}

The postpartum period begins after 2 hours postpartum and ends when the uterine organs return to their pre-pregnancy condition, usually lasting for 6 weeks or 42 days, but physiologically and psychologically will recover within 3 months. One of the goals of postpartum care is to provide counseling about breastfeeding and improve the development of good relationships between mothers and children (Sulfianti, 2021). Breast milk is breast milk that is produced from a woman's breast as a result of the interaction between progesterone, estrogen, prolactin, and oxytocin during pregnancy. The breast will develop in form and function in preparing for the breastfeeding stage. In the early phase of pregnancy, the breast ducts grow larger and develop lobes and alveoli. The changes in the shape structure resulted in a larger size, gentler, and heavier breasts.

The secretion of the hormone prolactin produced in the pituitary gland increases during pregnancy, which helps stimulate milk production after delivery. During pregnancy, prolactin, estrogen, and progesterone hormones will trigger the synthesis and secretion of colostrum, which consists of large amounts of carbohydrates and proteins without fat. Colostrum is only secreted during the early stages after delivery. When the estrogen and progesterone hormones decrease in number, the hormone prolactin stimulates the gland cells to produce. The oxytocin hormone secretes milk from the alveolus to the nipple. Breast milk flows when the baby is fed. The baby's suckling stimulates the nipples and therefore increases the prolactin hormone. Therefore, prolactin and the oxytocin hormone produce and release breast milk when stimulated by the baby's sucking. However, milk production will stop for two or three days if there is no stimulation from the baby's sucking (Ricci 2012).

Milk production is strongly influenced by the prolactin hormone and lactation control and suppression of 
lactation function. In a breastfeeding mother, there are two reflexes, each of which plays a role in the production of milk, the prolactin reflex and the Letdown reflex. The letdown reflex coincides with the formation of prolactin by the adenohypophysis; the stimulation that comes from the baby's sucking is continued to the neurohypophysis which is then produced by oxytocin. Through the bloodstream, this hormone is transported to the uterus which can cause uterine contractions so that the involution of the organ occurs. Oxytocin that reaches the alveoli will affect the myoepithelium cells. Contraction of the cells will squeeze the milk that has been made from the alveoli and enter the ductulus system which then flows through the lactiferous ducts into the baby's mouth. (TaufanNugroho 2014)

Breast milk production is very strongly influenced by psychological factors. Mothers who are depressed, sad, lack of self-confidence and various forms of emotions and tension will reduce the volume or even stop milk production, and cause the release of adrenaline which triggers vasoconstriction of blood vessels in the alveoli. This reaction will affect the letdown reflex, block the flow of milk, and create breast engorgement (Soetjiningsih, 2014). Techniques to increase milk production include breast care, breast exercise, breast massage and oxytocin massage. Breast care aims at making it easier for the breasts to secrete milk production through the baby's active sucking and avoid difficulty for the baby to suckle by doing massage, and Breast care also stimulates receptors in the ductal system, causing the ducts become wide and soft, so it will helping in releasing oxytocin from the posterior pituitary gland properly. (Sutrisminah and Alfiyati, 2013)

\section{MATERIALS \& METHODS}

This research design uses a quantitative analytic survey with a cross sectional approach. In this research design, the independent and dependent variables are measured and collected at the same time. (Sumantri, 2011)

\section{Statistical analysis}

Bivariate analysis has a purpose to analyze the relationship between two variables with Chi-Square statistical test. Chi-Square test is used to see the effect of the independent variable with the dependent. The analysis technique carried out is Chi-Square analysis using a 95\% confidence degree with $5 \%$, so that if the $\mathrm{P}$ value ( $p$ value) $<0.05$ means the statistical calculation results are significant (significant) or indicate there is a relationship between the dependent variable and the independent variable, and if the $\mathrm{p}$ value $>0.05$ means that the results of statistical calculations are not meaningful or there is no relationship between the dependent variable and the independent variable. (Sumantri, 2011)

\section{RESULT}

\section{Bivariate Analysis}

\begin{tabular}{|c|c|c|c|c|c|c|c|c|}
\hline \multirow{3}{*}{ Breastfeeding Technique } & \multicolumn{6}{|c|}{ Breast Engorgement } & \multirow{3}{*}{$\begin{array}{c}p \text { - } \\
\text { value }\end{array}$} & \multirow{3}{*}{$\boldsymbol{\alpha}$} \\
\hline & \multicolumn{2}{|c|}{ Yes } & \multicolumn{2}{|c|}{ No } & \multicolumn{2}{|c|}{ Total } & & \\
\hline & $\mathbf{N}$ & $\%$ & $\mathbf{N}$ & $\%$ & $\mathbf{n}$ & $\%$ & & \\
\hline Correct & 5 & 14 & 17 & 48 & 22 & 63 & \multirow{3}{*}{0,02} & \multirow{3}{*}{0,05} \\
\hline Wrong & 10 & 28 & 3 & 8 & 13 & 37 & & \\
\hline Total & 15 & 42 & 20 & 56 & 35 & 100 & & \\
\hline
\end{tabular}

Based on table 1 above, it shows that from 35 respondents, 22 respondents with correct breastfeeding techniques were found, from 22 respondents with correct breastfeeding techniques who experienced breast engorgement as many as 5 respondents and did not experience breast engorgement as many as 17 respondents, and obtained respondents with wrong breastfeeding techniques as many as 13 
respondents found that there were 10 respondents who experienced breast engorgement, and 3 respondents who did not experience breast engorgement. Based on the results of the chi square test, it was found that-value $=0.02 \mathrm{a}<0.05$, which means $\mathrm{Ha}$ is accepted and $\mathrm{H} 0$ is rejected, so it can be concluded that there is an effect of breastfeeding technique on the occurrence of breast engorgement.

\begin{tabular}{|c|c|c|c|c|c|c|c|c|}
\hline \multirow{3}{*}{$\begin{array}{l}\text { Condition of } \\
\text { Breast Nipple }\end{array}$} & \multicolumn{6}{|c|}{ Breast Engorgement } & \multirow{3}{*}{$p$-value } & \multirow{3}{*}{$\mathbf{A}$} \\
\hline & \multicolumn{2}{|c|}{ Yes } & \multicolumn{2}{|c|}{ No } & \multicolumn{2}{|c|}{ Total } & & \\
\hline & $\mathbf{N}$ & $\%$ & $\mathbf{N}$ & $\%$ & $\mathbf{N}$ & $\%$ & & \\
\hline Prominent & 15 & 42 & 8 & 22 & 23 & 65 & \multirow{3}{*}{0,01} & \multirow{3}{*}{0,05} \\
\hline sinks & 12 & 34 & 0 & 0 & 12 & 12 & & \\
\hline Total & 27 & 76 & 8 & 22 & 35 & 77 & & \\
\hline
\end{tabular}

Based on table 2 above, it shows that from 35 respondents, 23 respondents with prominent nipples were found and 15 respondents experienced breast engorgement and 8 respondents did not experience breast engorgement. Respondents with sinking nipples were 12 respondents and all respondents experienced breast engorgement. Based on the results of the chi square test, -value $=0.01 \mathrm{a}<0.05$, which means $\mathrm{Ha}$ is accepted and $\mathrm{HO}$ is rejected, so it can be concluded that there is an effect of the condition of the mother's nipple with the occurrence of breast engorgement.

\begin{tabular}{|c|c|c|c|c|c|c|c|c|}
\hline \multirow{3}{*}{$\begin{array}{c}\text { Breast } \\
\text { Care }\end{array}$} & \multicolumn{6}{|c|}{ Kejadian Bendungan ASI } & \multirow{3}{*}{$\begin{array}{c}p \text { - } \\
\text { value }\end{array}$} & \multirow{3}{*}{$\alpha$} \\
\hline & \multicolumn{2}{|c|}{ Yes } & \multicolumn{2}{|c|}{ No } & \multicolumn{2}{|c|}{ Total } & & \\
\hline & $\mathbf{N}$ & $\%$ & $\mathbf{N}$ & $\%$ & $\mathbf{N}$ & $\%$ & & \\
\hline Done & 0 & 0 & 9 & 25 & 9 & 25 & \multirow{3}{*}{0,03} & \multirow{3}{*}{0,05} \\
\hline Not & 15 & 42 & 11 & 31 & 26 & 74 & & \\
\hline Total & 15 & 42 & 20 & 56 & 35 & 99 & & \\
\hline
\end{tabular}

Based on table 3 above, from 35 respondents, there were 9 respondents, who did breast care, and there were no mothers who experienced breast engorgement, and there were 26 respondents who did not in breast care and 15 respondents who experienced breast engorgement and there were 11 respondents that were not in breast engorgement. Based on the results of the chi square test, it was found that - value $=0.03$ $<0.05$, which means $\mathrm{Ha}$ is accepted and $\mathrm{H} 0$ is rejected, so it can be concluded that there is an effect of breast care on mothers with the occurrence of breast engorgement.

\section{DISCUSSION}

\section{The Effect of Breastfeeding}

Technique to the Breast Engorgement

Based on the results of the chi square statistical test, it was found that the variable of breastfeeding technique with a $\mathrm{p}$ value of $0.02<0.05$, which means that there is an effect of breastfeeding technique on the incidence of breast engorgement. Wrong breastfeeding behavior may cause sore nipple, breast milk does not come out optimally so that it affects subsequent milk production or is reluctant to breastfeed (Proverawati 2010). Breastfeeding techniques greatly affect the comfort of the baby when sucking breast milk. The baby's sucking will have an effect on the stimulation of subsequent milk production, but mothers often lack information about the benefits of breastfeeding and about the correct breastfeeding technique (Utami 2010). The main key to successful breastfeeding is to pay attention to the latching, so the correct latching then the areola enters the baby's mouth, so that the baby's mouth can milked.

A good example of latching is chin pressed against mother's breast, mouth wide open, lower lip turning downwards and most of the areola in baby's mouth. Before breast feeding, a little milk is taken out and smeared on the nipple and the surrounding areola (Maryunani 2009). The results of the study (Banginwar et al. 2011) show that the correct way of breastfeeding can be influenced by age, parity, maternal employment status, breast problems, gestational age, and birth weight. Added by 
(Riksani R, 2012) factors that affect the correct way of breastfeeding include the lack of knowledge and information about proper breastfeeding, hospital management which often does not apply inpatient care, and it is not uncommon for health facilities to provide formula milk to newborn babies

\section{The Effect of Breast Nipple Condition to the Breast Engorgement}

Based on the results of the chi square statistical test, it was found that the variable condition of the mother's nipple with a $\mathrm{p}$ value of $0.01<0.05$, which means that there is an influence of the condition of the mother's nipple with the occurrence of breast engorgement. This is in line with research conducted by (SevalKologlen 2018) where it was found that sore and sunken nipples made it difficult for mothers to breastfeed, resulting in breast engorgement. And in line with research (Anin Adriyani 2018) the relationship between the shape of the mother's nipple and the occurrence of breast engorgement in postpartum mothers, the results of the Fisher exact statistical test using SPSS version 16 for windows were obtained. It is known that the significant test value (p) is 0.000 and with a health level of $0.05 \%$, then $\mathrm{p}<\mathrm{x}$ indicates that there is a relationship between the shape of the nipple and the occurrence of breast engorgement in postpartum mothers. According to (Ai Yeye 2010), the factors that cause breast engorgement are incomplete emptying of the mammae, inactive baby sucking factors, breastfeeding positions or breastfeeding techniques, flat, concave, long, flat, and short nipples. The normal shape of the nipple is a protruding/prominent nipple where the mammary papilla is not flat, sunken, split, and short. In general, the nipples protrude, however, sometimes long, flat (flat nipples) or inverted nipples can be found. However, the shape of the nipple does not always affect the lactation process. The most important thing is that the nipple can be retracted so that it forms a teat-like protrusion into the baby's mouth so that the baby can suckle smoothly. (Margreek 2009)

\section{The Effect of Breast Care to the Breast Engorgement}

Breast care is breast care to make it easier for the breasts to produce milk and avoid difficulties when breastfeeding by doing breast massage. Breast care stimulates receptors in the ductal system, causing the ducts become wide and soft, thereby producing oxytocin from the posterior pituitary gland (Sutrisminah and Alfiyati 2013). Based on the results of the research, the results of the chi square statistical test were obtained, the variable breast care with a $\mathrm{p}$ value of $0.03<0.05$, which means that there is an effect of breast care on the occurrence of breast engorgement. This is in line with the research (Taqiyah, Sunarti, and Rais 2019) with the title of the effect of breast care on the occurrence of breast engorgement using the McNemar statistical test and using a computerized system with a significance level of $=0.05$. This is also in line with research according to (Hesti et al. 2017) that there was a significant increase in breast milk secretion in postpartum mothers after being given a combination of oxytocin massage and breast care in the experimental group compared to education and counseling about breast care in the control group. Thus, these results can be used as evidence to carry out oxytocin massage and breast care to increase milk secretion in postpartum mothers. Techniques to increase milk production include breast care, breast exercise, breast massage and oxytocin massage.

\section{CONCLUSION}

Based on the results of the chi square statistical test, it was found that the variable of breastfeeding technique with a $\mathrm{p}$ value of $0.02<0.05$, which means that there is an effect of breastfeeding technique on the occurrence of breast engorgement. Based on the results of the chi square statistical test, it was found that the variable condition of the mother's nipple with a $\mathrm{p}$ value of $0.01<0.05$, which means that there 
is an influence of the condition of the mother's nipple with the occurrence of breast engorgement. Based on the results of the chi square statistical test, it was found that the variable breast care had a $p$ value of $0.03<0.05$, which means that there was an effect of breast care on the occurrence of breast engorgement. It is recommended to health workers, especially midwives, to provide counseling on the importance of exclusive breastfeeding $0-6$ months and continued until the baby is 2 years old, as well as breast care to prevent the occurrence of breast engorgement at mothers so that mothers can breastfeed their babies according to the expected time limit.

\section{Conflict of Interest: None}

\section{REFERENCES}

1. Ai Yeye, Rukiyah. 2010. Asuhan Kebidanan 1. Jakarta: CV. Trans Info. Media.

2. Anin Adriyani. 2018. "Hubungan Bentuk Puting Susu Dengan Kejadian Bendungan ASI Pada Ibu Nifas.”

3. Banginwar, AshishS, AhmedA Toweir, RamC Goyal, and Fatima Ziyo. 2011. "Breastfeeding Practices: Positioning, Attachment (Latch-on) and Effective Suckling-A Hospital-Based Study in Libya.” Journal of Family and Community $\begin{array}{lll}\text { Medicine } & 18 & \text { (2): }\end{array}$ https://doi.org/10.4103/2230-8229.83372.

4. Data Dinkes UPT Puskesmes Ulaweng. 2021. "Data UPT Puskesmes Ulaweng." UPTD Puskesmes Ulaweng. 2021.

5. Departemen Kesehatan. 2018. Riset Kesehatan Dasar (Riskesdas), Laporan Nasional 2007. Badan Pene. Jakarta.

6. Depkes RI. 2017. "Profil Kesehatan Provinsi Sulawesi Selatan.” Profil Kesehatan Provinsi Sulawesi Selatan, 111.

7. Elad, D., Kozlovsky, P., Blum, O., Laine, A. F., Jack Po, M., Botzer, E., ...Sirae, L. Ben. 2014. "Biomechanics of Milk Extraction during Breast-Feeding. Proceedings of the National Academy of Sciences of the United States of America." https://doi.org/https://doi.org/10.1073/pnas. 1319798111.

8. Hesti, Kadek Yuli, Noor Pramono, Sri Wahyuni, Melyana Nurul Widyawati, and Bedjo Santoso. 2017. "Effect of
Combination of Breast Care and Oxytocin Massage on Breast Milk Secretion in Postpartum Mothers.” Belitung Nursing Journal 3 (6): 784-90. https://doi.org/10.33546/bnj.293.

9. Kab.Bone, Dinas Kesehatan. 2020. "Data Dinas Kesehatan Kabupaten Bone.” Dinkes Kabupaten Bone. 2020.

10. Maryunani, Anik. 2009. Asuhan Pada Ibu Dalam Masa Nifas (Postpartum). Edited by Nata Wijaya. 1st ed. Jakarta: Trans Info Media.

11. Mufdlilah. 2017. Kebijakan Pemberian Asi Eksklusif. Yogyakarta: Universitas 'Aisyiyah Yogyakarta.

12. Proverawati. 2010. Kapita Selekta ASI Dan Menyusui. Yogyakarta: Nuha Medika.

13. Ricci, Susan Scott. 2012. Essentials of Maternity, Newborn, and Women's Health Nursing: Third Edition. Essentials of Maternity, Newborn, and Women's Health Nursing: Third Edition.

14. Seval Kologlen. 2018. "Factors Affecting Exclusive Breastfeeding, Using Adaptive LASSO Regression." Https://Www.Ncbi.Nlm.Nih.Gov/Pmc/Artic les/PMC6048001/\# 6 (3).

15. Soetjiningsih. 2014. "Buku Ajar Asuhan Kebidanan Masa Nifas Dilengkapi Penuntun Belajar.” Makara Printing Plus, 1-146.

16. Sulfianti, Evita Aurilia Nardina, Julietta Hutabarat, Etni Dwi Astuti, Yanik Muyassaroh, Diki Retno Yuliani, Wanodya Hapsari, Ninik Azizah, Cahyaning Setyo Hutomo, Niken Bayu Argahen. 2021. Asuhan Kebidanan Pada Masa Nifas. Edited by Ronal Watrianthos. Yayasan Kita Menulis.press@kitamenulis.id.

17. Sumantri, Arif. 2011. Metode Penelitian Kesehatan. 1st ed. Jakarta: Kncana.

18. Sutrisminah, Emi, and Nur Alfiyati. 2013. "Benefit of Breast Massage Postpartum Uterine Involution.” Jurnal Involusi Kebidanan 3 (5): 39-45.

19. Taqiyah, Yusrah, Sunarti Sunarti, and Nur Fadilah Rais. 2019. "Pengaruh Perawatan Payudara Terhadap Bendungan Asi Pada Ibu Post Partum Di Rsia Khadijah I Makassar.” Journal of Islamic Nursing 4 (1): 12. https://doi.org/10.24252/join.v4i1. 7757.

20. Taufan Nugroho, DKK. 2014. Buku Ajar Asuhan Kebidanan Nifas. 1st ed. Yogyakarta: Nuha Medika. 
Mustar et.al. Health services of breast engorgement on the postpartum mothers at Bone Regency South Sulawesi

21. Utami, Roesli. 2010. Mengenal ASI Eksklusif. Jakarta: Trubus Argriwidya.

22. Wicak Tini Hia. 2020. "Efektivitas Pijat Oketani Terhadap Pencegahan Bendungan Asi Pada Ibu Postpartum Dan Post Seksio Sesarea.” Jurnal Ilmiah Panned 15 (2). https://doi.org/10.36911/pannmed.v15i2.72.
How to cite this article: Mustar, Hasnidar, Indryani. Health services of breast engorgement on the postpartum mothers at Bone Regency South Sulawesi. International Journal of Science \& Healthcare Research. 2021; 6(4):341-347. DOI: https://doi.org/10.52403/ ijshr.20211047 